\title{
“ARANA-DOCUMENTS” FROM EMAR
}

\author{
Masamichi YAMADA*
}

The publication of texts from Emar and its vicinity is still in progress. Besides the main corpus of Emar texts (D. Arnaud, Recherches au pays d'Aštata. Emar VI/1-4, Paris, 1985-1987), more than two hundred texts have been published by Arnaud and other scholars(1). They have been yielding additional, sometimes quite new, sources for the studies of this Middle Euphrates city during the period from the 13 th to the early 12th cen. B.C. Worthy of special mention among these texts would be, for example, TSABR 14 and 15 referring to an event which has been hitherto unknown to us.

The texts themselves are just ordinary documents of real estate sale by the urban authorities, i.e. the god Ninurta and the elders of Emar. In $T S A B R$ 14, for example, a certain Izrac-Dagan, son of Himaš, buys a KI. erșetu(2) for $1 / 2$ mina of silve from Ninurta and the elders. The transaction is written in due form. However, we find a strange account (11. 19-26) inserted between the transaction itself (11. 1-18) and the regulation concerning the payment of fines in the future (11. 27-32). Arnaud's translation of this unusual part of the text( 3$)$ is as follows (its transliteration is cited below):

19. Quand, pour le trés[or royal,] 23. pour l'argent et l'or,

20. trente mille (sicles d')argent 24. on livra et

(et) sept cents (sicles d')or 25. l'argent et l'or au trésor royal

21. on réclama à la ville, 26. on livra.

22. des cabanons et des maisons,

In $T S A B R$ 15, although the first half of the parallel part is lost, according to the preserved text the amount of money is "2,000 (shekels) of gold" (1. 5'). Admitting this difference, Arnaud argues that the mentioned "king" indicates the king of Carchemish and that these accounts concern tributes sent from Emar to the Hittites(4). Thus he tries to envision a situation where the urban authorities sold their own real estate in order to raise money for payment of the tributes to Carchemish as background of the real estate transactions in these texts.

* Graduate student, Tel Aviv University

Vol. XXIX 1993 
Although so far overlooked due to their poor state of preservation, similar accounts are also found in two other texts: Emar VI 153 and ASJ 12-T 2. Hence, all four could be texts concerning the alleged tributes to Carchemish. However, it is difficult to ascertain any connection with the Hittites there. In the following I shall attempt first to read the texts anew and then to provide an alternative interpretation of them. In this examination, since the interpretation of the word arana mentioned in these texts is the central issue, I shall refer to these four texts below altogether as the "ARANA-documents."

All of them are the documents of transaction in which Ninurta and the elders sell their real estate to individuals(5). Despite having this feature in common, these texts differ in terms of the kind of real estate, price in silver, scribal name and eponym year as follows:

\begin{tabular}{|c|c|c|c|c|}
\hline Text & Real Estate & Price & Scribe & Eponym Year \\
\hline$T S A B R 14$ & KI.erșetu & $1 / 2(!) \operatorname{mina}$ & $\phi$ & $\phi$ \\
\hline Emar VI 153 & KI.erșetu & $2 / 3$ mina & {$\left[\right.$ Rašap-ili] ${ }^{(6)}$} & {$\left[\right.$ Iphur]-Daga $\left[\begin{array}{ll}n & x\end{array}\right] ?(7)$} \\
\hline ASJ 12-T 2 & KI.erșetu & $2 / 3 \operatorname{mina}(8)$ & {$[$ Raša $] p$-ili } & Iphur-Dagan 2 \\
\hline$T S A B R 15$ & ? & [?] & Rašap-ili & Silla-Udha 1 \\
\hline
\end{tabular}

As in $T S A B R$ 14, the account in question is inserted between the main text of transaction and the regulation concerning the payment of fines in each case. I would like to cite here the texts (corrected on the basis of their handcopies) in the following order: TSABR 14:19-26; Emar VI 153 : 13-17; ASJ 12-T 2 : obv. $11+\mathrm{x}$-rev. 5'a ; TSABR $15: 4+\mathrm{x}-8^{\prime}$. The account is divided into three parts ( $\S \S$ I-III) for convenience's sake in discussion below (Note / : new line; boldface : variation) :

I. i-nu-ma DIŠ a-ra-[na LUGAL] / 30,000 KÙ.BABBAR 7 me-tì KÙ.GI / [i-nu-ma DIŠ $a-r] a-n a \quad 30,000 \quad$ KÙ.BABBAR / [2 li-mi KÙ.GI $]$ [i-nu-ma DIŠ $a-r a-n a] /\ulcorner 30,0007$ KÙ.BABBAR $2 l i-m i$ KÙ.GI / [i-nu-ma DIŠ a-ra-na 30,000 KÙ.BABBAR]/ 2 li-mi KÙ.GI

$\begin{array}{ll}\text { URU.KI } & i-r i \text {-šu } \phi / \\ \text { [UR]U.e-mar.KI / } & {[i-r i \text {-šu-ma }]} \\ \text { [U]RU.e-mar.KI } & i-r i-s ̌ s-m a /\end{array}$


URU.e-mar.KI / i-ri-šsu-ma

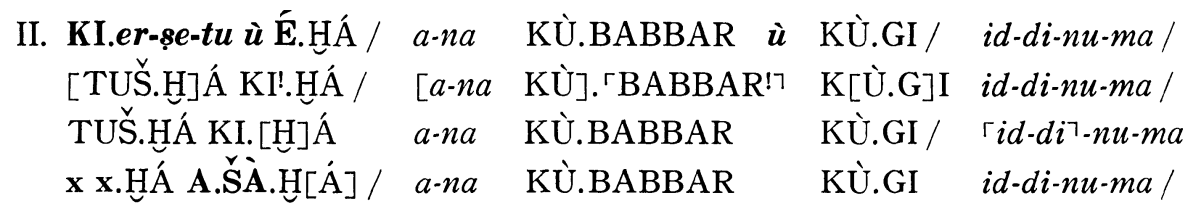

$\begin{array}{lllll}\text { III. KÙ.BABBAR } & \grave{u} \text { KÙ.GI } & a-n a & \text { a-ra-na LUGA[L]/ } & \text { id-di-nu } \boldsymbol{\phi} / \\ \text { [KÙ.BABBAR } & \text { KÙ.G]I } & a-n a & {[(a-) r] a-n a} & u b-l u !-m i / \\ \text { KÙ.BABBAR } & \text { KÙ.GI } & a-n a & \langle a\rangle-r a-n[a] / & u b-l u-m i \\ \text { KÙ.BABBAR } & \text { KÙ.GI } & a \cdot n a & \langle a\rangle-r a \cdot n[a] & u b-l u-[m i] /\end{array}$

\section{Remarks}

* These accounts are parallel in construction and content. But it is immediately apparent that only TSABR 14 among the ARANA-documents was written by a different scribe; this can easily be discerned according to grammar and phraseology, as well as handwriting.

I. While Arnaud reads a-na a-ra-[na LUGAL] in TSABR $14: 19$, what we find on his handcopy is not $a-n a$ but a DIŠ-sign. While it is true that the DIŚ-sign can stand for the preposition ana, such orthography is quite exceptional in this kind of Emar text, and indeed, ana is always written syllabically as $a$-na elsewhere in this text (11. 14, 15, 23, 25, 29, 30, 31). Moreover, note Arnaud's rendering of arana as "trésor." Even if the Akkadian noun arānu, basically meaning "chest," might have such a connotation( 9 ), the vowel -a for genitive case ending (see also § III) would be problematic. Thus arana can hardly be a common noun. Rather, these points would suggest that the DIŠ-sign should be regarded as the determinative ${ }^{m}$ preceding a PN

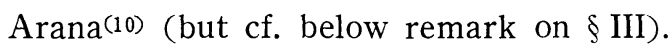

It is obvious that the amount of gold is different between TSABR 14 and the other three (700 vs. 2,000 shekels). Although, unfortunately, the latter texts are partially broken, it seems likely that all of them refer to the same amount of money. Here, the reading of ASJ 12-T 2: rev. 1' is crucial. A. Tsukimoto reads at the beginning of the line [1]5? ГGÍN7 KÙ. BABBAR. However, the sign following the number is not GíN but $\mathrm{SIG}_{7}$ (= $10,000)$ and it seems probable that the number itself is to be read as $3^{(11)}$. This reading would be supported by the fact that these three texts were 
written by the same scribe, Rašap-ili.

II. It is interesting to note that here the various plots of real estate (all in pl.) are categorized. In $T S A B R$ 14, since the KI.erșetu is classified in the same category as "house (É)," it is conceivable that the KI.erșetu is to be regarded as a kind of building (or a plot of land for housing)(12). A similar categorization can be also expected in Emar VI 153 and ASJ 12-T 2, the same kind of documents as the KI.erșetu sale. I would suggest, albeit tentatively, reading the first sign (KU, if not MA) as TUŠ (=šubtu), "dwelling place," and regarding the following KI as an abbreviation of KI.erșetu. Although, on the other hand, it is not certain how to read the first two signs in TSABR 15(13), it nevertheless seems likely that this real estate belonging to the same category of "field (A. Š̀̀)" (or land in general, excluding that for housing), distinct from the category of "house."

III. In TSABR 14, the reference to the "king (LUGAL)" and the use of a different verb nadānu, "to give," (cf. (w)abālu," to bring," in the other texts) immediately attract attention. Note also that here the DIŠ-sign is not written before arana. Furthermore, at least in $A S J 12-\mathrm{T} 2$ and TSABR 15, the sandhi (<*ana arana) is observed.

The problem here is how arana should be understood. In the above (remark on § I) I suggested its interpretation as a PN Arana, instead of a common noun arānu. In this case, he must have been a "king" as mentioned in $T S A B R 14: 25$ ( $(\mathrm{III})$. Thus $T S A B R 14: 19-26$ can be rendered as follows :

When Ara[na, the king], asked the city for 30,000 (shekels) of silver (and) 700 (shekels) of gold, KI.erșetus and houses were given (to the city) and the silver and gold were given to Arana, the kin[g].

Likewise rendered in the other three texts : for example, TSABR $15: 4+\mathrm{x}-8^{\prime}$ :

[When Arana] asked the city of Emar for [30,000 (shekels) of silver] (and) 2,000 (shekels) of gold, ...s (and) fields were given (to the city) and the silver (and) gold were brought to Arana.

On the other hand, the lack of the determinative ${ }^{m}$ (DIŠ-sign) and the occurrence of sandhi in \$ III may be regarded as indications refuting the interpreta- 
tion of arana LUGAL as "Arana, the king." In this regard, it seems to me that examination of the regulations concerning the payment of fines, which follow these accounts, will shed light on this question(14).

In the ARANA-documents, a claimant is required to pay 1,000 shekels of silver to each of the following two or three bodies:

$\begin{array}{lccc}\text { Text } & \text { Ninurta } & \text { City } & \text { Palace } \\ \text { TSABR 14 } & + & + & + \\ \text { Emar VI 153(15) } & + & + & + \\ A S J \text { 12-T 2 } & + & + & - \\ \text { TSABR } 15 & + & + & -\end{array}$

Since the urban authorities (i.e. Ninurta and the elders) are documented as selling their real estate in these texts, it stands to reason that "Ninurta" and the "city" are mentioned as payees(16). However, the references to the "palace" in TSABR 14:31 and possibly in Emar VI 153:20 are enigmatic. Note that the payment of fines to three bodies is not attested to elsewhere in the Emar texts; usually only one or two are recorded. Futhermore, the fact that no member of the royal family of Emar appears in these two texts is significant, since in other texts, whenever the "palace" is mentioned as a payee, a king or prince of Emar appears as a withness, and occasionally as a person involved in the transaction(17). How can we explain this?

The most probable explanation would be obtained by assuming that Arana was the king of Emar; it therefore stands to reason that the palace (of Emar) should be referred to as the payee. Indeed, according to the above-mentioned understanding of the accounts, the king was involved in real estate transactions with the city in the past. Such an analysis of these regulations strengthens the interpretation of "Arana, the king." Moreover, it strongly suggests his identity as the king of Emar(18).

Returning to the accounts in question, in the passages cited above, one may recognize one or more situations where the king Arana asked the city of Emar for money, delivered various plots of real estate, and in exchange, received money from the city. Then, what function do they fulfill in the ARANA-documents? Assuming this reading of the texts is correct, it would appear that these earlier accounts serve to legitimatize the real estate transactions recorded in the main parts of the ARANA-documents: they 
guarantee that the plots of real estate being sold by Ninurta and the elders are among those which the city had properly acquired from the king Arana in the past(19). Thus these accounts may be understood as well-integrated parts of the ARANA-documents(20).

On the basis of the above discussions, we may reasonably assume that Arana was the king of Emar and that during his reign there was at least one royal real estate sale on a large scale to the city of Emar. Taking into account the fact that no king named Arana is known in the Emar texts published so far, this would lead us to deduce that the ARANA-documents preserve some historical memory of a king of Emar prior to the 13th cen. B.C(21). This point, however, cannot be determined at present. Thus this interpretation of the ARANA-documents would admittedly remain a hypothesis. Hopefully more texts from Emar and its vicinity will enable discussion on this issue in the future.

Finally, it is worthwhile to note that the urban authorities never bought real estate elsewhere. Hitherto known means of real estate acquisition by the authorities were confiscations by Ninurta(22), later those plots of real estate were sold by Ninurta and the elders of $\operatorname{Emar}^{(23)}$; Why is it that other Emar texts do not refer to the purchase of real estate by the urban authorities? It seems to me that the ARANA-documents provide one of the answers: it is because they had already bought quantities of real estate from Arana.

\section{Notes}

(1) For refs. see J. Ikeda, "Linguistic Identification of an Emar Srcibe," Orient 28 (1992), p. 39 n. 4 with the following additions: M. Yoshikawa and E. Matsushima, "Tokyo Lexical Tablet_-Preliminary Report," Oriento 23/2 (1980), pp. 1-19 (Japanese); F.M. Fales, Prima dell'alfabeto (Studi e documenti 4), Venezia, 1988, pp. 201208 (nos. 65-68) ; H. Gonnet and F. Malbran-Labat, "Un contrat akkadien avec sceau hittite: AO 28366," Anatolica 16 (1989-1990), pp. 1-6; S. Dalley and B. Teissier, "Tablets from the Vicinity of Emar and Elsewhere," Iraq 54 (1992), pp. 83-109, pls. x-xiv (nos. 1-8).

The following abbreviations will be used below in referring to Emar texts (with text no.) : ASJ 12-T=A. Tsukimoto, "Akkadian Tablets in the Hirayama Collection (I)," ASJ 12 (1990), pp. 177-259; ASJ 13-T=idem, "Akkadian Tablets in the Hirayama Collection (II)," ASJ 13 (1991), pp. 275-333; Emar VI=D. Arnaud, Recherches au pays d'Aštata. Emar VI/3, Paris, 1986; TSABR=idem, Textes syriens de l'âge du Bronze récent (Aula Orientalis Supplementa 1), Barcelona, 1991.

(2) KI.erșetu is a term of real estate used in the Middle Euphrates region. 
Although Arnaud, assuming a word kirșitu, renders it as "cabanon," orthographically it should be regarded as a logogram KI followed by a gloss erșetu ("land"). On the other hand, however, in view of its usage, KI.ersetu is apparently dealt with as a kind of house in the Emar texts. Thus its meaning, "land" or "house," is in debate and a possible solution, a plot of land (for housing), has found wide acceptance. See C. Wilcke, "Kirșitu, ein Phantomwort," NABU 1990/35; Tsukimoto, ASJ 12, pp. 179, 211 n. 5; J. Huehnergard, "More on KI.erșetu at Emar," NABU 1991/58; C. Zaccagnini, "Ceremonial Transfers of Real Estate at Emar and Elsewhere," VO 8 (1992), pp. 42-48; cf. W. Mayer, "Kirșītum "abgeschiedenes Gebäude", UF 21 (1989), pp. $269 f$.

(3) TSABR, p. 42.

(4) Ibid., p. 16.

(5) Although TSABR 15 is broken, this point cannot be doubted. Note also that the "city of Emar (URU.e.mar)" is mentioned in TSABR 14:10 instead of the "elders of Emar (LÚ.MEŠ.ši-bu-ut URU.e-mar.KI)" in Emar VI $153: 8$ and ASJ 12-T 2:8.

(6) As Tsukimoto noted ( $A S J$ 12, pp. 182f.), Emar VI 153 and ASJ 12-T 2 contain quite similar witness lists (see also TSABR 15). Although a similar witness list is also found in a document written by Dagan-bëlu (Emar VI 150), common features observed on grammar and phraseology (see below) as well as handwriting (esp. the DA-sign) would strongly suggest that Emar VI 153, ASJ 12-T 2 and TSABR 15 were all written by the same scribe, Rašap-ili.

(7) Possibly read [ITI x x MU ip-hur $\left.{ }^{\mathrm{d}}\right] d a \cdot g a[n] 1[(+1) . K A M . M A]$ (1. 32); cf. ]x x[ (Arnaud, Emar VI/3, p. 169). The eponym year of Iphur-Dagan (2nd year) is also mentioned in $A S J$ 13-T 33: 17f. (Rašap-ili's document).

(8) Not 1/4 (1. 10); cf. Tsukimoto, ASJ 12, p. 181.

(9) Cf. $C A D \mathrm{~A} / 2$, p. 231 ("chest, coffer, cashbox, coffin"); $A H w$, p. 65a ("Kasten, Lade, Sarg").

(10) E.g. " $a \cdot r a-n a$ (AT $286: 3$ ); see D.J. Wiseman, "Ration Lists from Alalakh IV," JCS 13 (1959), p. 50.

(11) On the photograph ( $A S J 12$, p. 231), (at least) 3 is certain (but cf. handcopy, ibid., p. 213) and in fact Tsukimoto also once read $\ulcorner 37$ in his "Kingship and Rural Community-On recent discussions about the social history of Syria in the Late Bronze Age," Bulletin of the Ancient Orient Museum 5 (1983), p. 251 (Japanese).

(12) See above n. 2.

(13) This real estate is mentioned three times in TSABR 15. Arnaud reads $\mathrm{DU}_{6}-l a$ ! (11. 1, 6) and $\mathrm{DU}_{6}-l u^{!}(1.9)$ for tìlu, "tell" (but see his own note in TSABR, p. 44). Note that the first sign can be read as KI in each case.

(14) TSABR 14:27-32; Emar VI $153: 18-21$ (see the following note); ASJ 12-T 2: rev. 5'b-8'; TSABR $15: 9^{\prime}-12$ '.

(15) We would suggest reading: (18) [ša ur-r $] a-a m$ š $[e-r] a-a m$ KI.er-se-ta

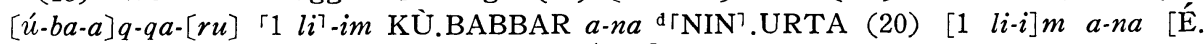

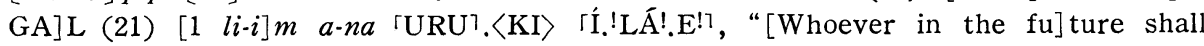
[lay c]la[im] on the KI.erșetu will pay 1,000 (shekels) of silver to Ninurta, $[1,00] 0$ (shekels of silver) to [the palac]e (and) $[1,00] 0$ (shekels of silver) to the city"; cf. ASJ 12-T 2: rev. 5'b-8'; TSABR 15: 9'-12'.

(16) As usual: e.g. Emar VI 1f., 4, 9, 139, 147f., 150, 155; ASJ 12-T 7; TSABR $2-4,6$ f., $9,13,16-19$, etc.

(17) E.g. Emar VI 8, 10f., 94f., 97, 125, 137f., 140-142, 158, 172; ASJ 12-T 8, 10; TSABR $12,54,59 \mathrm{f} ., 62,82$, etc. But not vice versa.

(18) This identification may be further supported by another point. If two different 
amounts of money (see above) reflect two occasions of selling real estate from Arana to the city, it would suggest that his authority over Emar was not temporary but more or less permanent. To make sure, although Emar was once placed under vassalage to (probably) Mitanni/Hurri and then of Hatti (and Carchemish,) it is in. conceivable that Arana was the king of any of these lands. On the other hand, even if arana LUGAL might mean the "royal treasury," it is undoubtedly of Emar, not of Carchemish.

(19) It is not in order to raise money for payment that Ninurta and the elders sold the real eatate to individuals, since at the time of writing each ARANA-document (i.e. when signing the contract was on going) the silver and gold had already been paid to Arana (iddinü $/ u b l \bar{u}$ in $\$$ III).

(20) It is worthwhile to note that the accounts of the confiscation of real estate by Ninurta (for refs. see below $n .22$ ) share the same function in the documents, in which Ninurta and the elders sell the acquired real estate to individuals.

(21) The oldest Emar text (except for Emar VI 536 in Old Babylonian) from the reign of Iași-Dagan (TSABR 1) would not antedate the 13th cen. B.C. ; see Yamada, "An Introduction to the Chronology of the Emar Texts: Absolute Chronology and Synchronism," Oriento (forthcoming; Japanese).

(22) Emar VI $1: 11-16 \mathrm{a} ; 11: ?-21 \mathrm{a} ; 144: 10-13 ; 145: 1-4 ; 197: 13 \mathrm{~b}-17,20$ '-21'a ; ASJ 12-T $7: 9-11$; TSABR $13: 9-12$; cf. also Emar VI $154: 5$ '-7'.

(23) Except for Emar VI 197, a will of a certain Ikun-Ra. 